\title{
Caloric restriction in C57BL/6J mice mimics therapeutic fasting in humans
}

\author{
Lisa B Mahoney, Christine A Denny and Thomas N Seyfried*
}

Address: Biology Department, Boston College, Chestnut Hill, MA, USA

Email: Lisa B Mahoney - mahoneli@bc.edu; Christine A Denny - dennych@bc.edu; Thomas N Seyfried* - thomas.seyfried@bc.edu

* Corresponding author

Published: 18 May 2006

Lipids in Health and Disease 2006, 5:13 doi:10.1186/1476-5IIX-5-13

This article is available from: http://www.lipidworld.com/content/5/I//3

(c) 2006 Mahoney et al; licensee BioMed Central Ltd.

This is an Open Access article distributed under the terms of the Creative Commons Attribution License (http://creativecommons.org/licenses/by/2.0), which permits unrestricted use, distribution, and reproduction in any medium, provided the original work is properly cited.
Received: 27 March 2006

Accepted: 18 May 2006

\begin{abstract}
Background: Caloric restriction (CR) has long been recognized as a dietary therapy that improves health and increases longevity. Little is known about the persistent effects of $C R$ on plasma biomarkers (glucose, ketone bodies, and lipids) following re-feeding in mice. It is also unclear how these biomarker changes in calorically restricted mice relate to those observed previously in calorically restricted humans.

Results: Three groups of individually housed adult female C57BL/6) (B6) mice ( $n=4 /$ group) were fed a standard rodent chow diet either: (I) unrestricted (UR); (2) restricted for three weeks to reduce body weight by approximately $15-20 \%(\mathrm{R})$; or (3) restricted for three weeks and then refed unrestricted (ad libitum) for an additional three weeks (R-RF). Body weight and food intake were measured throughout the study, while plasma lipids and levels of glucose and ketone bodies ( $\beta$-hydroxybutyrate) were measured at the termination of the study. Plasma glucose, phosphatidylcholine, cholesterol, and triglycerides were significantly lower in the R mice than in the UR mice. In contrast, plasma fatty acids and $\beta$-hydroxybutyrate were significantly higher in the $R$ mice than in the UR mice. CR had no effect on plasma phosphatidylinositol levels. While body weight and plasma lipids of the R-RF mice returned to unrestricted levels upon re-feeding, food intake and glucose levels remained significantly lower than those prior to the initiation of CR.

Conclusion: $\mathrm{CR}$ establishes a new homeostatic state in B6 mice that persists for at least three weeks following ad libitum re-feeding. Moreover, the plasma biomarker changes observed in B6 mice during $C R$ mimic those reported in humans on very low calorie diets or during therapeutic fasting.
\end{abstract}

\section{Background}

Caloric restriction (CR) has long been recognized as a natural therapy that improves health and extends longevity in humans and rodents [1-7]. CR diminishes inflammation and oxidative stress that occurs from aging by decreasing the production of reactive oxygen species $[1,8,9]$. In rodents and primates, CR lowers plasma insulin, cholesterol, triglycerides, and insulin-like growth fac- tor (IGF-1) levels, while elevating plasma high-density lipoprotein (HDL) levels [10-14]. These changes in plasma metabolites reduce risk for atherosclerosis, diabetes, and obesity [15]. Additional health benefits of CR likely result from reduced glucose levels and elevated ketone bodies ( $\beta$-hydroxybutyrate), which reduce oxygen free radicals and increase the $\Delta \mathrm{G}^{\prime}$ of ATP hydrolysis $[6,14,16,17]$. 
Numerous studies in humans have used fasting as a treatment for obesity, diabetes, and cancer [18-21]. Therapeutic fasting differs from starvation in mobilizing fat rather than protein for energy. Very low calorie diets (approximately 300 kilocalories per day) often produce effects that are similar to those seen during therapeutic fasting [2224]. During the initial stages of a full food fast (water only), blood glucose levels are initially maintained by the mobilization of stored glycogen (glyogenolysis). As glycogen stores become depleted, the body gradually transitions to fatty acids and ketone bodies for additional energy. Although gluconeogenesis also increases, this is insufficient alone to provide enough energy, especially for the brain [21,25-28]. Continued fasting decreases total plasma cholesterol, low-density lipoprotein (LDL) levels, and triglycerides, while elevating fatty acids $[20,29,30]$. Since the brain does not generally metabolize fatty acids for energy [31], ketone bodies provide the largest source of energy for the brain during prolonged fasting [32]. Ketone bodies are a more efficient energy source than either glucose or fatty acids because they are more reduced (a greater hydrogen/carbon ratio) than pyruvate and do not uncouple the mitochondrial proton gradient as occurs with fatty acid metabolism [17].

Few studies have examined the longer-term effects of CR or fasting on the concentration of plasma metabolites following ad libitum re-feeding. Most previous studies examined biomarker changes following brief periods of refeeding (approximately 4 days) [33-35]. In general, refeeding restored levels of cholesterol, triglycerides, glucose, ketone bodies, fatty acids, and body weight to the levels seen prior to the initiation of $\mathrm{CR}$ or fasting [15,18,34-37]. No prior studies, to our knowledge, have determined to what extent CR-induced plasma biomarker changes persist in mice following ad libitum re-feeding for several weeks. It is also unclear how plasma biomarker changes in mice under CR relate to those observed in humans under food restricted diets.

In this study, we found that three weeks of moderate CR in adult female C57BL/6J (B6) mice significantly reduced plasma glucose, cholesterol, triglycerides and body weight, while elevating fatty acids and ketone bodies. Although ad libitum re-feeding for three weeks restored body weight and most CR-induced biomarker changes, food intake and glucose levels remained lower in the R-RF mice than in the UR mice. These findings suggest that the health benefits of CR persist for at least three weeks in B6 mice thus producing a physiological state more energy efficient than that prior to CR. Moreover, the plasma biomarker changes found in B6 mice during three weeks of CR mimic those reported in humans during a very low calorie diet or therapeutic fasting.

\section{Results}

Compared to the UR mice, the R mice were healthier and more active as assessed by ambulatory and grooming behavior. There were no signs of vitamin or mineral deficiency in the $\mathrm{R}$ mice according to standard criteria [38]. These findings are consistent with the well-established health benefits of mild to moderate CR in rodents and why it is unnecessary to supplement with vitamins and minerals during short-term (up to 12 weeks) CR studies $[3,4,39-41]$.

\section{Influence of caloric restriction and re-feeding on food intake and body weight}

Adult virgin female mice were used for this study because their food intake and body weights are relatively stable from about 120 to 170 days of age (Figs. 1, 2A and 2B). The average total food intake for the UR group during weeks $2-4$ was $86.9 \pm 2.2 \mathrm{~g}(\mathrm{n}=4)$, and over the next three weeks was $87.5 \mathrm{~g}(\mathrm{n}=2)$. The amount of food provided for the R mice was initially $60 \%$ (40\% restriction) of that eaten prior to the initiation of CR (pretrial period). The amount of food given to the $\mathrm{R}$ mice was then adjusted each day $( \pm 5 \%)$ to achieve a final body weight reduction of approximately $15 \%$. The average total food intake for all restricted mice $(n=8)$ during the three week restriction period was $52.2 \pm 1.5 \mathrm{~g}$. This represents an overall average total food restriction of approximately $40 \%$ over the three week period. Body weight was chosen as an endpoint for CR rather than food intake because body weight is a more stable variable than food intake, which differs significantly among mice, even within the same strain. [4,16]. A $15 \%$ body weight reduction achieved by a $40 \%$ restriction in food represents a moderate caloric restriction for adult mice [4]. Body weight was reduced in the $\mathrm{R}$ group at day 15 and remained significantly lower than that of the UR group ( $\mathrm{p}<0.01$ ) until day 30 . On the day of re-feeding, the R-RF mice binge ate and consumed approximately twice as much food ( $8.5 \mathrm{~g} /$ day/mouse) as they did during the pretrial period (about $4.2 \mathrm{~g} / \mathrm{day} /$ mouse). Food intake in the R-RF mice decreased rapidly, but remained greater than that of the UR mice until day 33 (Fig. 2A). The average total food intake for the R-RF group $(n=4)$ for the three week re-feeding period, including the three day binge period, was $76.9 \pm 2.0 \mathrm{~g}$. Interestingly, the food intake following the binge period (from day 38 through the end of the study) was less in the R-RF mice $(3.35 \mathrm{~g} /$ day/mouse $(n=4)$ ) than in the UR mice $(4.17 \mathrm{~g} / \mathrm{day} /$ mouse $(n=2)$ (Fig. $2 A)$ ). The R-RF mice also ate significantly less food per day during this period than they did during the pretrial period $(4.08 \mathrm{~g} / \mathrm{day} /$ mouse $(\mathrm{n}=4)(\mathrm{p}<$ $0.05)$ ) as determined by the paired $t$-test. Despite reduced food intake, the body weights of the R-RF mice returned to the levels observed during the pre-trial period and were similar to the body weights of the UR mice (Fig. 2B). 


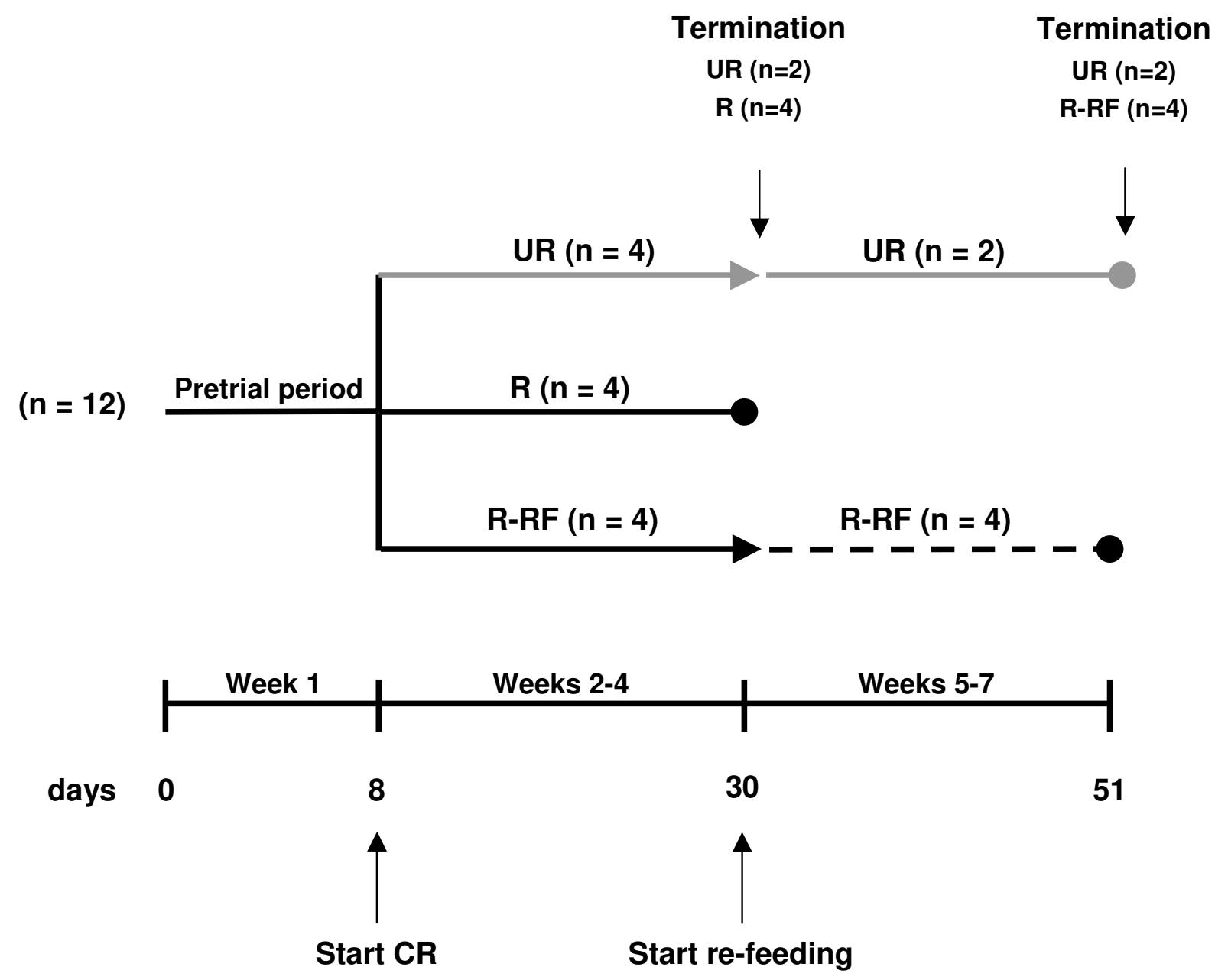

Figure I

Flow chart of the study design. Body weight and food intake were measured every other day over the seven day pre-trial period. All mice received food ad libitum during the pre-trial period. After the pre-trial period, the mice were divided into three groups ( $n=4$ mice/group) where the average body weight of each group was similar. The mice in each group were then fed the same diet in different amounts: I) the standard chow diet unrestricted (UR), 2) the standard chow diet restricted to achieve an approximate 15-20\% body weight reduction from the pre-trial weight (R), or 3) the standard chow diet restricted to achieve an approximate 15-20\% body weight reduction from the pre-trial weight for a period of three weeks, followed by unrestricted re-feeding for a period of three weeks (R-RF). Each mouse in the R and the R-RF groups served as its own control for body weight reduction as previously described [16]. Based on food intake and body weight during the pre-trial period, food in the R and the R-RF groups was reduced until each mouse achieved the target weight reduction of approximately I5-20\%. The study was terminated and plasma was collected for two UR mice and four R mice on day 30 , and for the remainder of the mice on day $5 \mathrm{I}$.

Influence of $C R$ and re-feeding on plasma glucose and $\beta$ hydroxybutyrate levels

Glucose levels were $41 \%$ less in the R mice than in the UR mice (Table 1). Although the glucose levels increased following re-feeding in the R-RF mice, the levels remained significantly lower than those in the UR mice. Plasma $\beta$ - hydroxybutyrate levels were $367 \%$ greater in the $\mathrm{R}$ mice than in the UR mice (Table 1). Once re-fed, the plasma $\beta$ hydroxybutyrate levels for the R-RF mice returned to those measured in the UR mice. These findings are consistent with our previous studies that $\beta$-hydroxybutyrate levels are increased under CR and that circulating $\beta$-hydroxybu- 

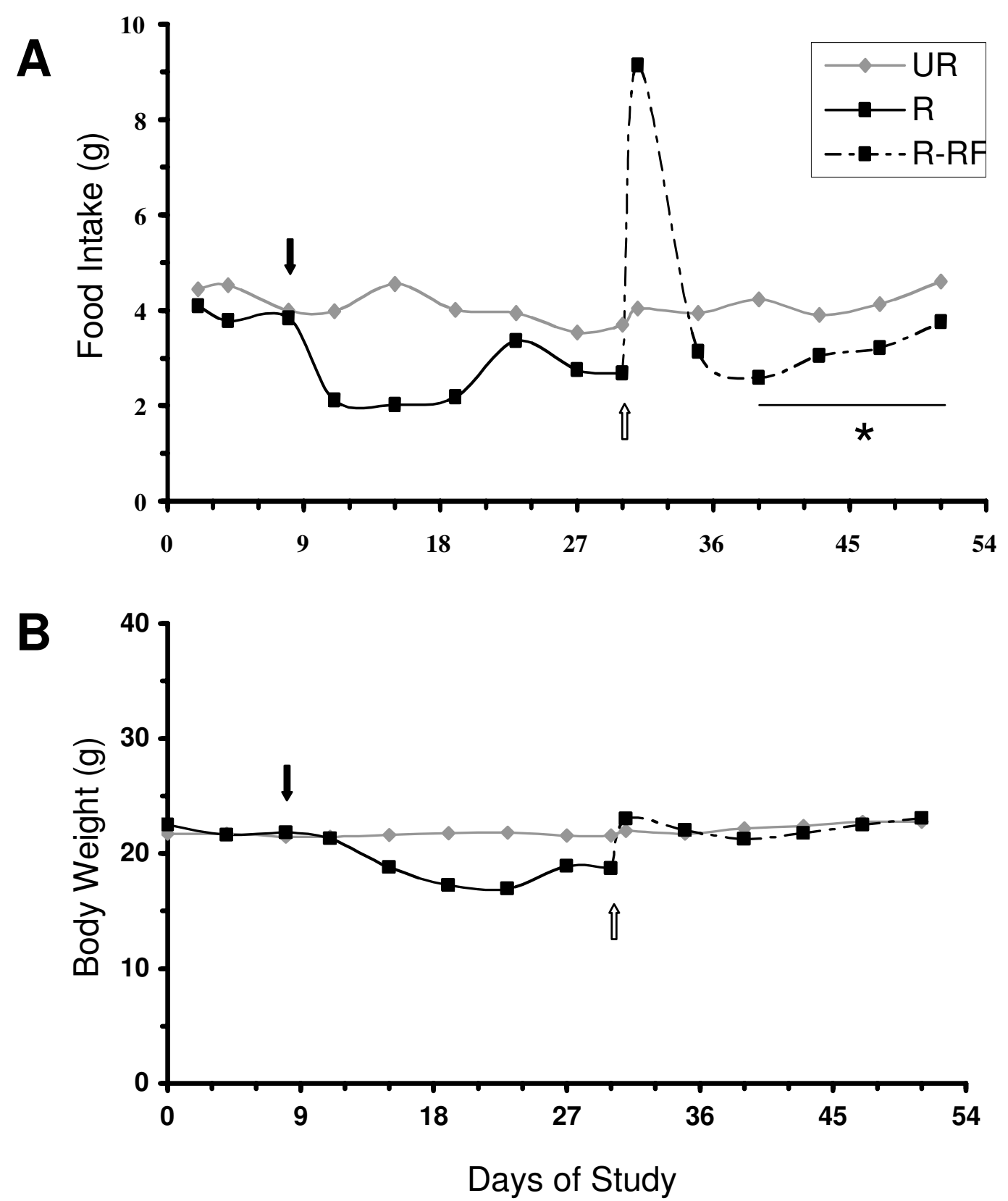

\section{Figure 2}

Influence of CR and re-feeding on food intake (A) and body weight (B). Values are expressed as means and 4-8 mice were analyzed in each group. The black arrow indicates the initiation of CR on day 8 . The white arrow indicates the initiation of ad libitum re-feeding on day 30 . The * indicates that the food intake average of the days 38 to 50 of re-feeding for the R-RF mice was significantly less than their food intake prior to initiation of $C R$, as determined by the paired $t$-test. 
Table I: Influence of Caloric Restriction and Re-feeding on Plasma Metabolites in B6 Mice ${ }^{a}$

\begin{tabular}{|c|c|c|c|c|c|}
\hline Metabolites & UR & $\mathrm{R}$ & Difference(\%) & R-RF & $\mathrm{F}^{\mathrm{d}}(2,9)$ \\
\hline Glucoseb & $15.5 \pm 0.86$ & $9.1 \pm 1.83 * *$ & 41 & $|2.5 \pm 1.6|^{*}$ & 18.3 \\
\hline$\beta$-hydroxybutyrate ${ }^{b}$ & $0.3 \pm 0.12$ & $1.4 \pm 0.13^{* *}$ & 367 & $0.3 \pm 0.05$ & $|4| .4$ \\
\hline \multicolumn{6}{|l|}{ Neutral lipids c } \\
\hline Triglycerides & $2.4 \pm 0.63$ & $1.0 \pm 0.16 *$ & -58 & $2.5 \pm 1.00$ & 6.1 \\
\hline Cholesterol & $0.5 \pm 0.23$ & $0.2 \pm 0.06^{*}$ & -60 & $0.4 \pm 0.14$ & 3.7 \\
\hline Phosphatidylcholine & $2.8 \pm 0.53$ & $1.7 \pm 0.25 * *$ & -39 & $2.8 \pm 0.30$ & 10.3 \\
\hline \multicolumn{6}{|l|}{ Acidic Lipids c } \\
\hline Fatty acids & $0.3 \pm 0.08$ & $0.8 \pm 0.05 * *$ & 167 & $0.3 \pm 0.05$ & 69.7 \\
\hline Phosphatidylinositol & $0.2 \pm 0.03$ & $0.2 \pm 0.01$ & 0 & $0.2 \pm 0.03$ & 1.2 \\
\hline
\end{tabular}

a Values represent the mean $\pm 95 \% \mathrm{Cl}$. Four independent samples were analyzed per group.

b Values are expressed as mM.

c Determined from densitometric scanning of HPTLC as shown in Figures 3 and 4 . Values are expressed as $\mathrm{mg}$ lipid $/ \mathrm{ml} \mathrm{plasma.}$

$\mathrm{d} / \mathrm{F} /$ ratio and degree of freedom (df) obtained from one way analysis of variance.

Astericks indicate that the value is significantly different from that of the control at the $* p<0.05$ and $* * p<0.01$ as determined by ANOVA followed by Fisher's PLSD

tyrate levels are inversely related to circulating glucose levels $[4,7,16]$.

\section{Influence of $C R$ and re-feeding on neutral and acidic lipids} The influence of $\mathrm{CR}$ and re-feeding on the qualitative and quantitative distribution of plasma neutral lipids and acidic lipids in B6 mice is shown in Figs. 3 and 4, respectively, and in Table 1. Triglycerides, cholesterol, and phosphatidylcholine were significantly reduced, while fatty acids were significantly elevated in the $\mathrm{R}$ mice when compared to the UR mice. All plasma lipids in the R-RF mice returned to the levels seen in the UR mice. In contrast to phosphatidylcholine, which was reduced in the $\mathrm{R}$ mice and returned to normal levels in the R-RF mice, CR and refeeding had no effect on plasma levels of phosphatidylinositol. Although sphingomyelin and lysophosphatidylcholine were detected in the plasma of all groups (Fig. 3), no statistically significant differences were found among the groups for these lipids due to sample variability. It is important to mention that the solvent front (SF) does not include lipids, but contains slight impurities from the organic solvents used in the developing system.

\section{Discussion}

Reliable biomarkers can be useful for gauging the degree and efficacy of CR as a therapy for a variety of diseases to include: aging, neurological and neurodegenerative diseases, and cancer. Our data show that reductions in plasma glucose, cholesterol, phosphatidylcholine, and triglycerides, combined with elevations of ketone bodies ( $\beta$-hydroxybutyrate), and fatty acids, are robust biomarker changes for CR in the B6 mouse. Similar changes in glucose and ketone bodies have been observed in other mouse strains and rodent models under CR $[6,7,16,42]$.
Cholesterol esters, sphingomyelin, and lysophosphatidylcholine are less reliable plasma biomarkers of CR due to variability between individual mice. It is interesting to note that phosphatidylinositol levels were unchanged as a result of CR and re-feeding, suggesting that this lipid might serve as an internal control for assessing the degree of change in other plasma biomarkers of CR.

Little is known about the persistent effects of CR on plasma biomarkers (glucose, ketone bodies, and lipids) following re-feeding in mice. Previous studies showed that CR-induced biomarker changes return to levels seen prior to CR following brief periods of ad libitum re-feeding (approximately 4 days) $[34,35]$. Our results showed that all biomarkers in the R-RF mice returned to the levels seen prior to CR with the exception of food intake and glucose levels. Since blood glucose levels are directly related to food intake, the persistent reduction in blood glucose reflects the reduction in food intake. These findings suggest that the R-RF mice have established a new, more efficient homeostatic state, in which reduced food intake can maintain body weight similar to that seen during the pretrial period.

Our results are in agreement with those of other investigators [43-45] who observed an energy conservation mechanism due to a decrease in thermogenesis, allowing less energy to be lost as heat and more accumulated as protein, fat, and glycogen. This increase in metabolic efficiency could be the result of several factors involved in homeostasis, but most likely is the result of a decrease in total heat production of the thermoregulatory system. In addition to increasing ATP production, while reducing oxygen consumption, ketone body metabolism also reduces produc- 
tion of damaging free radicals $[17,46]$. For these and other reasons, Veech has described ketone bodies as "super fuel" [17]. We suggest that the health benefits of CR result in part from a bioenergetic mechanism made more efficient through an increase in ketone body metabolism coupled with a decrease in glucose metabolism. Further studies will be needed to identify those physiological changes within the mitochondria that contribute to or underlie the more efficient metabolic state.

The physiological relationship between CR in mice and humans is unclear. Although rodents and other animals can be maintained on calorie-restricted diets for prolonged periods [47], this draconian dietary practice is impractical in humans. Since the basal metabolic rate of mice is about seven times that of humans [48], it is unlikely that similar degrees of CR will have similar physiological effects in man and mouse. Indeed, a review of the literature generally shows that the plasma biomarker changes we observed in B6 mice, which received approximately $60 \%$ of the food given to the UR mice on a daily basis, are generally similar to those observed previously in humans during very low calorie diets or during "water only" therapeutic fasting (Table 2). While prolonged therapeutic fasting (for one to three weeks) can be healthy for some humans [49], severe food deprivation beyond a few days is unhealthy in rodents due to increased oxidative stress [50]. Our findings indicate that moderate CR in B6 mice mimics very low calorie diets or therapeutic fasting in humans. Hence, the numerous health benefits documented in mice following CR may be experienced in humans on very low calorie diets or during periodic therapeutic fasting.

\section{Conclusion}

CR establishes a new homeostatic state in $\mathrm{B} 6$ mice that persists for at least three weeks following ad libitum refeeding. Moreover, the plasma biomarker changes observed in B6 mice during CR mimic those reported in humans on very low calorie diets or during therapeutic fasting.

Table 2: Influence of Fasting/Very Low Calorie Diet on Plasma Metabolites in Humansa

\begin{tabular}{|c|c|c|c|c|c|c|}
\hline Metabolites & Length (days) & Unrestricted & Fasted & Difference (\%) & References & \\
\hline \multirow[t]{2}{*}{ Glucose } & 21 & 7.06 & 4.39 & -38 & Owen et al. 1998 & [19] \\
\hline & $21-35$ & 5.11 & 3.89 & -24 & Streja et al. I 977 & [58] \\
\hline \multirow[t]{4}{*}{$\beta$-hydroxybutyrate } & 2 & 0.03 & 1.67 & $5 . E+03$ & Pan et al. 2000 & [59] \\
\hline & 3 & 0.03 & 3.15 & I.E+04 & & \\
\hline & 21 & 0.19 & 4.60 & $2 . E+03$ & Owen et al. 1998 & [19] \\
\hline & $21-35$ & 0.11 & 4.56 & $4 . E+03$ & Streja et al. I 977 & [58] \\
\hline \multicolumn{7}{|l|}{ Neutral lipids } \\
\hline \multirow[t]{3}{*}{ Triglycerides } & 7 & 3.46 & 2.50 & -28 & Balazsi et al. 1983 & [29] \\
\hline & 14 & 3.46 & 1.77 & -49 & & \\
\hline & 28 & 1.13 & 0.95 & -16 & Shoji et al. 1992 & [30] \\
\hline \multirow[t]{6}{*}{ Cholesterol } & 7 & 4.90 & 6.73 & 37 & $\begin{array}{l}\text { Savendahl and } \\
\text { Underwood } 1999\end{array}$ & [20] \\
\hline & 7 & 5.48 & 5.16 & -6 & Balazsi et al. 1983 & [29] \\
\hline & 14 & 5.48 & 4.36 & -20 & & \\
\hline & 14 & 5.14 & 4.01 & -22 & $\begin{array}{l}\text { Schouten et al. } \\
|98|\end{array}$ & {$[60]$} \\
\hline & 15 & 5.39 & 4.43 & -18 & $\begin{array}{l}\text { Cominacini et al. } \\
\text { |99| }\end{array}$ & {$[61]$} \\
\hline & 28 & 5.22 & 4.21 & -19 & Shoji et al. 1992 & [30] \\
\hline \multirow[t]{2}{*}{ LDL Cholesterol } & 7 & 2.91 & 2.96 & 2 & Balazsi et al. 1983 & [29] \\
\hline & 14 & 2.91 & 2.43 & -16 & & \\
\hline $\begin{array}{l}\text { Phosphatidylcholin } \\
\mathrm{e}\end{array}$ & 7 & 2.21 & 2.39 & 8 & $\begin{array}{l}\text { Savendahl et al. } \\
1997\end{array}$ & [62] \\
\hline \multicolumn{7}{|l|}{ Acidic Lipids } \\
\hline \multirow{2}{*}{ Fatty acids } & 21 & 0.84 & 1.19 & 42 & Owen et al. 1998 & [19] \\
\hline & $21-35$ & 0.51 & 0.85 & 67 & Streja et al. 1977 & [58] \\
\hline
\end{tabular}

a Values are expressed as $\mathrm{mM}$. 


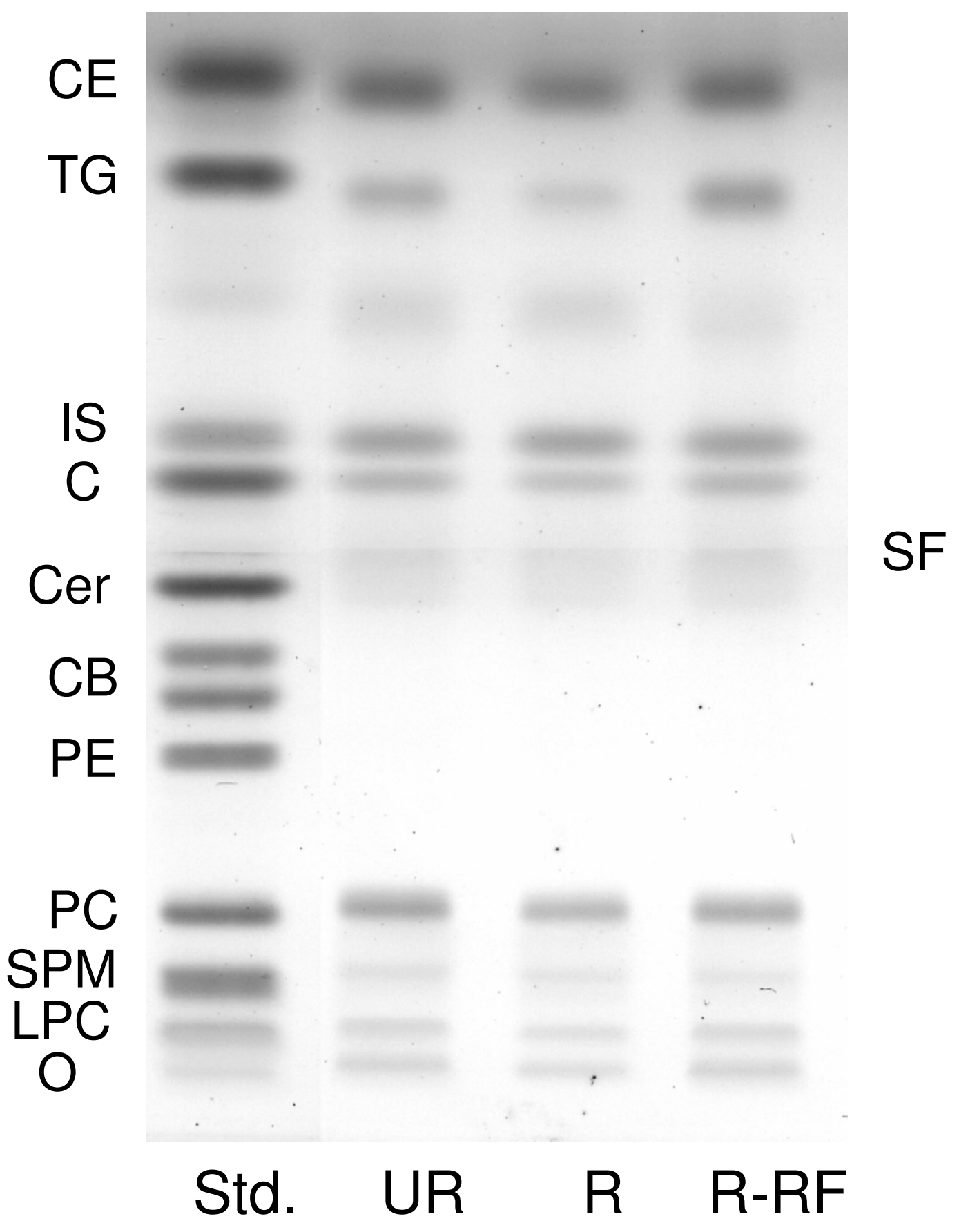

\section{Figure 3}

HPTLC of plasma neutral lipids in B6 mice. The amount of neutral lipids spotted per lane was equivalent to $2.5 \mu$ l of plasma. The plate was developed as described in the Methods. CE, cholesterol esters; TG, triglycerides; IS, internal standard; C, cholesterol; Cer, ceramide; CB, cerebrosides (doublet); PE, phosphatidylethanolamine; PC, phosphatidylcholine; SM, sphingomyelin; LPC, lysophosphatidylcholine; $\mathrm{O}$, origin; and SF, solvent front of the first developing solvent system. 


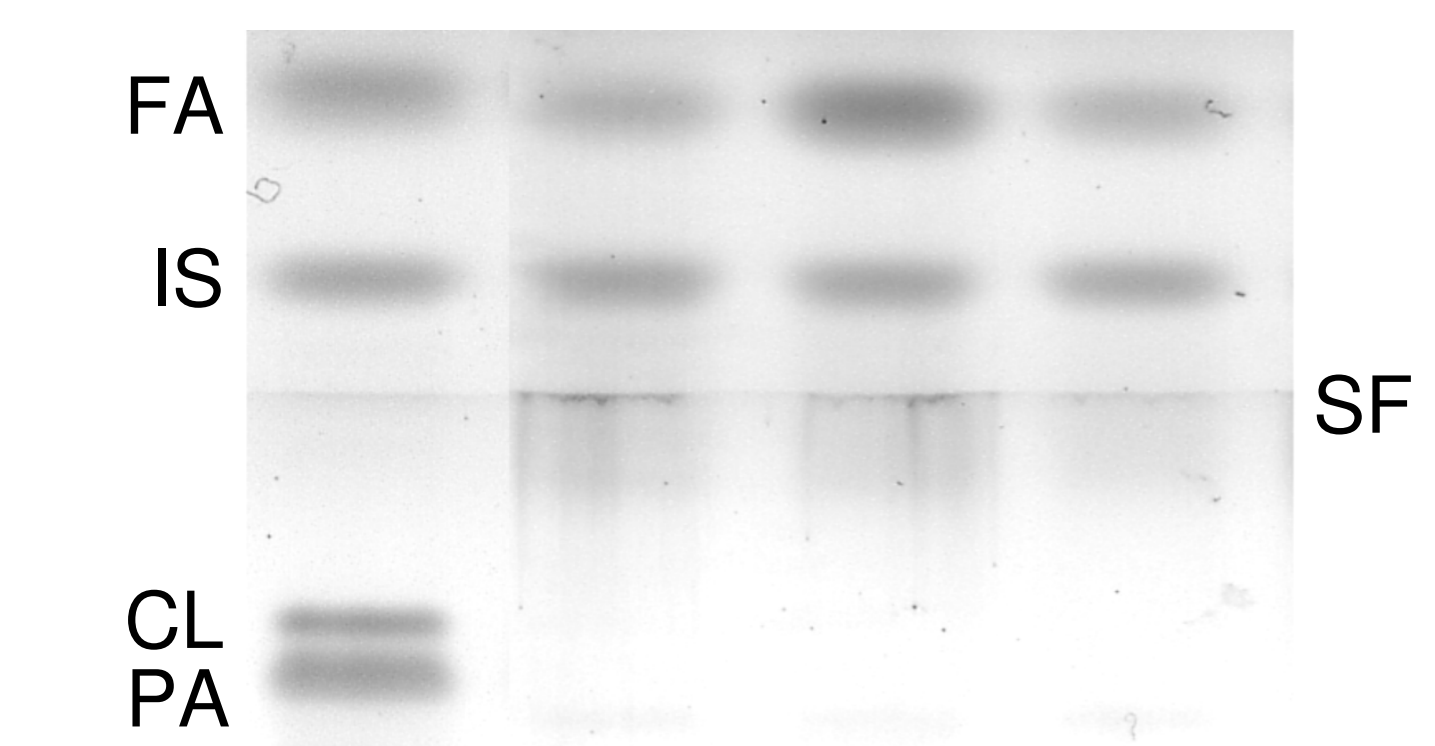

\section{SULF}

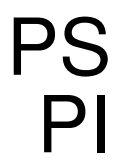

O

\section{Std. \\ UR \\ $\mathrm{R}$ \\ R-RF}

\section{Figure 4}

HPTLC of plasma acidic lipids in B6 mice. The amount of acidic lipids spotted per lane was equivalent to I5 $\mu$ l of plasma. The plate was developed as described in the Methods. FA, fatty acids; IS, internal standard; CL, cardiolipin; PA, phosphatidic acid; Sulf, sulfatides (doublet); PS, phosphatidylserine; PI, phosphatidylinositol; O, origin; and SF, solvent front of the first developing solvent system.

\section{Methods}

\section{Mice}

C57BL/6J (B6) mice were obtained from the Jackson Laboratory (Bar Harbor, ME, USA) and were propagated in the Boston College Animal Care Facility. Adult female mice were used and were housed individually in plastic cages with filter tops containing Sani-Chip bedding (P.J. Murphy Forest Products Corp., Montville, NJ, USA. Cotton nesting pads were provided to all mice for warmth for the duration of the experiment, and room was maintained 
at $22^{\circ} \mathrm{C}$ on a $12 \mathrm{~h}$ light $-12 \mathrm{~h}$ dark cycle. The procedures for animal use were in strict accordance with the NIH Guide for the Care and Use of Laboratory Animals and were approved by the Institutional Animal Care Committee.

\section{Caloric restriction, body weight and food intake measurements}

All mice received PROLAB RMH 3000 chow (LabDiet, Richmond, IN, USA). This contained a balance of mouse nutritional ingredients and delivers $4.4 \mathrm{kcal} \mathrm{g}^{-1}$ gross energy, where fat, carbohydrate, protein, and fiber comprised 55, 520, 225, and $45 \mathrm{~g} \mathrm{~kg}^{-1}$ of the diet, respectively. A total of 12 singly caged, adult female B6 mice were used for the study. The mice were matched for age $(120 \pm 8$ days), sex (virgin females), and body weight $(22.0 \pm 1.0$ g). The experimental design for implementation of $\mathrm{CR}$ and re-feeding is outlined in Fig. 1. Body weight and food intake measurements were taken at approximately the same time of day (11:00 AM - 1:00 PM) for all mice. Body weight was measured every two days for the UR and R mice. The R-RF mice were weighed daily during the binge period, and every two days thereafter. Food intake for the UR mice was determined daily by subtracting the weight of the food pellets remaining in the food hopper after two days from the initial amount given (approximately $80 \mathrm{~g}$ ) and dividing the difference by two. For mice in the $\mathrm{R}$ and R-RF groups, weighed food pellets were dropped directly into each cage for easy access. Water was provided ad libitum for all mice.

\section{Glucose and $\beta$-hydroxybutyrate measurements}

Mice were sacrificed with isofluorane (Halocarbon Laboratories, River Edge, NJ, USA) and blood was collected into heparinized tubes from either the retro-orbital sinus or the heart. The blood was centrifuged at $6,000 \times g$ for 10 min, the plasma was collected, and aliquots were stored at $-80^{\circ} \mathrm{C}$ until analysis. Plasma glucose concentration was measured spectrophotometrically using the Trinder Assay (Sigma-Aldrich, St. Louis, MO, USA). The ketone body $\beta$ hydroxybutyrate was measured enzymatically using the Stanbio $\beta$-Hydroxybutyrate LiquiColor ${ }^{\circledR}$ assay kit (Stanbio, Boerne, TX, USA).

\section{Lipid isolation and purification}

Acidic and neutral lipids were isolated and purified from plasma using modifications of previously described procedures [51-53]. Briefly, total lipids were extracted by adding chloroform $\left(\mathrm{CHCl}_{3}\right)$ and methanol $\left(\mathrm{CH}_{3} \mathrm{OH}\right)$ to an aliquot of plasma to produce a ratio of $\mathrm{CHCl}_{3}: \mathrm{CH}_{3} \mathrm{OH}$ : aqueous plasma (30:60:8 by vol). The plasma volume was used to calculate the volume of $\mathrm{CHCl}_{3}$ and $\mathrm{CH}_{3} \mathrm{OH}$ needed to achieve the ratio. Solvent $\mathrm{A}\left(\mathrm{CHCl}_{3}: \mathrm{CH}_{3} \mathrm{OH}\right.$ : $\mathrm{dH}_{2} 0 ; 30: 60: 8$ by vol) was added to increase the total volume of each sample. The solution was placed on a mag- netic stirrer at room temperature overnight and then centrifuged for $20 \mathrm{~min}$ at $1200 \times \mathrm{g}$. The supernatant was collected and the pellet was washed with solvent $A$, placed on the stirrer for $30 \mathrm{~min}$, and centrifuged as before. The supernatants were combined.

The neutral lipids and acidic lipids were purified using DEAE-Sephadex (A-25, Pharmacia Biotech, Upsala, Sweden) column chromatography as previously described $[52,53]$. The total lipid mixture was applied to a DEAESephadex column with a bed volume of $1.2 \mathrm{ml}$ that had been equilibrated prior with solvent A. Neutral lipids were eluted from the column by washing two times with $20 \mathrm{ml}$ of solvent A. Acidic lipids were then eluted from the column with $30 \mathrm{ml}$ of solvent $\mathrm{B}\left(\mathrm{CHCl}_{3}: \mathrm{CH}_{3} \mathrm{OH}: 0.8 \mathrm{M} \mathrm{Na}\right.$ acetate, 30:60:8 by vol). The neutral lipid fraction was dried using rotary evaporation, washed with $1 \mathrm{ml} \mathrm{dH_{2 }} 0$ and $4 \mathrm{ml} \mathrm{CHCl}_{3}: \mathrm{CH}_{3} \mathrm{OH}$ (2:1 by vol), and centrifuged at $1200 \times g$ to partition neutral lipids into the Folch lower phase $[54,55]$. The upper phase was removed and the lower phase was washed once with the Folch pure solvent upper phase [PSUP] $\left(\mathrm{CHCl}_{3}: \mathrm{CH}_{3} \mathrm{OH}: \mathrm{dH}_{2} \mathrm{O}, 3: 48: 47\right.$ by $\mathrm{vol})$ and centrifuged again at $1200 \times \mathrm{g}$ for $15 \mathrm{~min}$. The upper phase was removed and the lower phase was then evaporated under a stream of nitrogen, re-suspended in 5 $\mathrm{ml}$ of $\mathrm{CHCl}_{3}: \mathrm{CH}_{3} \mathrm{OH}(2: 1$ by vol $)$, and stored at $4{ }^{\circ} \mathrm{C}$.

The acidic lipid fraction was evaporated under vacuum and $7 \mathrm{ml}$ of $\mathrm{CHCl}_{3}: \mathrm{CH}_{3} \mathrm{OH}(1: 1$ by vol) was added. $\mathrm{CHCl}_{3}(3.5 \mathrm{ml})$ and $\mathrm{dH}_{2} \mathrm{O}(2.6 \mathrm{ml})$ were added, and the mixture was inverted, vortexed, and centrifuged to partition acidic lipids into the lower phase. The upper phase was removed and the lower organic phase was washed once with $4.5 \mathrm{ml}$ of the Folch PSUP and centrifuged. The upper phase was removed and the lower phase was evaporated under a stream of nitrogen, re-suspended in $5 \mathrm{ml}$ of $\mathrm{CHCl}_{3}: \mathrm{CH}_{3} \mathrm{OH}\left(2: 1\right.$ by vol), and stored at $4{ }^{\circ} \mathrm{C}$.

\section{Qualitative and quantitative analysis of plasma lipids}

Neutral and acidic lipids were analyzed qualitatively by high-performance thin-layer chromatography (HPTLC) following modifications of previously described methods $[7,51,52,56]$. Lipids were spotted on $10 \times 20$ Silica gel 60 HPTLC plates (E. Merck, Darmstadt, Germany) using a Camag Linomat III auto-TLC spotter (Camag Scientific Inc., Wilmington, NC, USA). The amount of plasma per lane was equivalent to $15 \mu \mathrm{l}$ for acidic lipids and $2.5 \mu \mathrm{l}$ for neutral lipids. To enhance precision, an internal standard (oleoyl alcohol) was added to the neutral and acidic lipid standards and the plasma samples as previously described [52]. Purified lipid standards were purchased from Matreya, Inc. (Pleasant Gap, PA, USA), Avanti Polar Lipids, Inc. (Alabaster, AL, USA), and Sigma (St. Louis, MO, USA). 
For neutral and acidic lipids, the plate was developed to a height of 4.5 and $6.0 \mathrm{~cm}$, respectively, with chloroform : methanol : acetic acid : formic acid : water (35:15:6:2:1 by vol), and was then developed to the top with hexanes : diisopropyl ether : acetic acid (65:35:2 by vol). Neutral and acidic lipids were visualized by charring with $3 \%$ cupric acetate in $8 \%$ phosphoric acid solution, followed by heating in an oven at $160-170^{\circ} \mathrm{C}$ for $7 \mathrm{~min}$ as previously described $[7,51,52,56]$.

The density and percentage distribution of the individual lipid bands was determined by scanning the plate on a Personal Densitometer SI with ImageQuant software (Molecular Dynamics, Sunnyvale, CA, USA) for neutral and acidic lipids. The density values for each neutral and acidic lipid were fit to a standard curve of the respective lipid and used to calculate individual concentrations as described previously [52]. All plasma lipid concentrations are expressed as milligram of lipid per milliliter of plasma.

\section{Statistical analysis}

Analysis of variance (ANOVA) followed by a Fisher's protected least significant difference (PLSD) test were used to evaluate the significance of differences between the UR, R, and R-RF groups. A paired $t$-test was used to analyze differences within the R-RF group (Statview, v. 5.0) [57]. In each figure, $n$ designates the number of individual mice analyzed.

\section{Abbreviations}

Adenosine triphosphate (ATP)

Caloric restriction $(\mathrm{CR})$

High-density lipoprotein (HDL)

High-performance thin-layer chromatography (HPTLC)

Low-density lipoprotein (LDL)

Restricted (R)

Restricted/Re-fed (R-RF)

Unrestricted (UR)

\section{Competing interests}

The author(s) declare that they have no competing interests.

\section{Authors' contributions}

LBM participated in the design of the study, carried out the study, performed the lipid analysis, performed the statistical analysis, and helped to draft the manuscript. CAD participated in the design of the study, performed statisti- cal analysis, and coordinated and helped to draft the manuscript. TNS designed the study and helped to draft the manuscript. All authors read and approved the final manuscript.

\section{Acknowledgements}

The authors would like to thank John Mantis, Purna Mukherjee, Rena Baek, Youngho P. Kim, and Rosemarie Keefe for technical assistance. We also thank Dr. Richard McGowan, S.J., for assistance with statistical analyses. The work was supported in part from NIH grants (HD39722 and CA 02135 ), the Boston College Research Expense Fund, and the National Tay-Sachs and Allied Disease Association Inc. (NTSAD).

\section{References}

I. Frame LT, Hart RW, Leakey JE: Caloric restriction as a mechanism mediating resistance to environmental disease. Environ Health Perspect 1998, 106 Suppl I:313-324.

2. McCay CM, Crowell MF, Maynard LA: The effect of retarded growth upon the length of life span and upon the ultimate body size. 1935. Nutrition 1989, 5(3): 155-7|; discussion 172 .

3. Weindruch R, Naylor PH, Goldstein AL, Walford RL: Influences of aging and dietary restriction on serum thymosin alpha I levels in mice. J Gerontol 1988, 43(2):B40-2.

4. Greene AE, Todorova MT, McGowan R, Seyfried TN: Caloric restriction inhibits seizure susceptibility in epileptic EL mice by reducing blood glucose. Epilepsia $200 \mathrm{I}, \mathbf{4 2}$ (II): I37I-I 378.

5. Duan W, Guo Z, Jiang H, Ware M, Mattson MP: Reversal of behavioral and metabolic abnormalities, and insulin resistance syndrome, by dietary restriction in mice deficient in brainderived neurotrophic factor. Endocrinology 2003, I 44(6):2446-2453.

6. Greene AE, Todorova MT, Seyfried TN: Perspectives on the metabolic management of epilepsy through dietary reduction of glucose and elevation of ketone bodies. J Neurochem 2003, 86(3):529-537.

7. Denny CA, Kasperzyk JL, Gorham KN, Bronson RT, Seyfried TN: Influence of caloric restriction on motor behavior, longevity, and brain lipid composition in Sandhoff disease mice. J Neurosci Res 2006.

8. Morgan TE, Xie Z, Goldsmith S, Yoshida T, Lanzrein AS, Stone D, Rozovsky I, Perry G, Smith MA, Finch CE: The mosaic of brain glial hyperactivity during normal ageing and its attenuation by food restriction. Neuroscience 1999, 89(3):687-699.

9. Lee CK, Weindruch R, Prolla TA: Gene-expression profile of the ageing brain in mice. Nat Genet 2000, 25(3):294-297.

10. Anson RM, Guo Z, de Cabo R, lyun T, Rios M, Hagepanos A, Ingram DK, Lane MA, Mattson MP: Intermittent fasting dissociates beneficial effects of dietary restriction on glucose metabolism and neuronal resistance to injury from calorie intake. Proc Natl Acad Sci U S A 2003, I00(10):621 6-6220.

11. Roth GS, Ingram DK, Lane MA: Caloric restriction in primates and relevance to humans. Ann N Y Acad Sci 200I, 928:305-3I5.

12. Shimokawa I, Higami Y, Tsuchiya T, Otani H, Komatsu T, Chiba T, Yamaza H: Life span extension by reduction of the growth hormone-insulin-like growth factor-I axis: relation to caloric restriction. Faseb J 2003, 17(9): I 108-1 I09.

13. Mukherjee P, El-Abbadi MM, Kasperzyk JL, Ranes MK, Seyfried TN: Dietary restriction reduces angiogenesis and growth in an orthotopic mouse brain tumour model. $\mathrm{Br} J$ Cancer 2002, 86(10): 1615-162|.

14. Seyfried TN, Sanderson TM, El-Abbadi MM, McGowan R, Mukherjee $\mathrm{P}$ : Role of glucose and ketone bodies in the metabolic control of experimental brain cancer. $\mathrm{Br} J$ Cancer 2003, 89(7): 1375-1382.

15. Verdery RB, Walford RL: Changes in plasma lipids and lipoproteins in humans during a 2-year period of dietary restriction in Biosphere 2. Arch Intern Med 1998, I 58(8):900-906.

16. Mantis JG, Centeno NA, Todorova MT, McGowan R, Seyfried TN: Management of multifactorial idiopathic epilepsy in EL mice with caloric restriction and the ketogenic diet: role of glucose and ketone bodies. Nutr Metab (Lond) 2004, I (I): I I . 
17. Veech RL: The therapeutic implications of ketone bodies: the effects of ketone bodies in pathological conditions: ketosis, ketogenic diet, redox states, insulin resistance, and mitochondrial metabolism. Prostaglandins Leukot Essent Fatty Acids 2004, 70(3):309-319.

18. Goldrick RB, Hirsch J: Serial Studies on the Metabolism of Human Adipose Tissue. li. Effects of Caloric Restriction and Refeeding on Lipogenesis, and the Uptake and Release of Free Fatty Acids in Obese and Nonobese Individuals. J Clin Invest 1964, 43: 1793-1804.

19. Owen OE, Smalley KJ, D'Alessio DA, Mozzoli MA, Dawson EK: Protein, fat, and carbohydrate requirements during starvation: anaplerosis and cataplerosis]. Am J Clin Nutr 1998, 68(1): I2-34.

20. Savendahl L, Underwood LE: Fasting increases serum total cholesterol, LDL cholesterol and apolipoprotein B in healthy, nonobese humans. J Nutr 1999, I 29(II):2005-2008.

21. Cahill GF): Starvation in man. N Engl J Med 1970, 282( I 2):668-675

22. Marliss EB, Murray FT, Nakhooda AF: The metabolic response to hypocaloric protein diets in obese man. J Clin Invest 1978 62(2):468-479.

23. Vaisman N, Sklan D, Dayan Y: Effect of moderate semi-starvation on plasma lipids. Int J Obes 1990, I4(I 2):989-996.

24. Zahouani A, Boulier A, Hespel JP: Short- and long-term evolution of body composition in 1389 obese outpatients following a very low calorie diet (Pro'gram I 8 VLCD). Acta Diabetol 2003, 40 Suppl I:SI 49-50.

25. Gordon RS], Cherkes A: Unesterified fatty acid in human blood plasma. J Clin Invest 1956, 35(2):206-2 I2.

26. Cahill GFJ: Insulin, diabetes and adipose tissue. $A$ brief review. J Mich State Med Soc 1960, 59:1513-1518.

27. Shapiro B, Chowers I, Rose G: Fatty acid uptake esterification in adipose tissue. Biochim Biophys Acta 1957, 23(1): I I5-I 20.

28. Yaffee S, Gold A, Sampugna J: Effects of prolonged starvation on plasma free fatty acid levels and fatty acid composition of myocardial total lipids in the rat. J Nutr 1980, I I O( I 2):2490-2496.

29. Balazsi I, Karadi I, Somogyi A, Jona G, Romics L: Serum lipids during starvation in obesity. Acta Med Hung 1983, 40(2-3): I33-138.

30. Shoji T, Nishizawa $Y$, Koyama H, Hagiwara S, Aratani H, Sasao K, Kishimoto $H$, Tanishita H, Morii H: High-density-lipoprotein metabolism during a very-low-calorie diet. Am J Clin Nutr 1992 56(I Suppl):297S-298S.

31. Yang SY, He XY, Schulz $\mathrm{H}$ : Fatty acid oxidation in rat brain is limited by the low activity of 3-ketoacyl-coenzyme $A$ thiolase. J Biol Chem 1987, 262(27): I3027-I 3032.

32. Owen OE, Morgan AP, Kemp HG, Sullivan JM, Herrera MG, Cahill GF): Brain metabolism during fasting. I Clin Invest 1967, 46(10): $1589-1595$.

33. Kmiec Z, Pokrywka L, Kotlarz G, Kubasik J, Szutowicz A, Mysliwski A: Effects of fasting and refeeding on serum leptin, adiponectin and free fatty acid concentrations in young and old male rats. Gerontology 2005, 5 I (6):357-362.

34. Poullain MG, Vacher D, Cezard JP, Girard-Globa A: Serum lipids and apolipoproteins in the rat refed after starving: influence of the molecular form of nitrogen (protein, peptides, or free amino acids). Metabolism 1989, 38(8):740-744.

35. McGarry JD, Meier JM, Foster DW: The effects of starvation and refeeding on carbohydrate and lipid metabolism in vivo and in the perfused rat liver. The relationship between fatty acid oxidation and esterification in the regulation of ketogenesis. J Biol Chem I 973, 248(I):270-278.

36. Sauer LA, Dauchy RT: Blood nutrient concentrations and tumor growth in vivo in rats: relationships during the onset of an acute fast. Cancer Res 1987, 47(4): 1065-1068.

37. Cleary MP, Jacobson MK, Phillips FC, Getzin SC, Grande JP, Maihle NJ: Weight-cycling decreases incidence and increases latency of mammary tumors to a greater extent than does chronic caloric restriction in mouse mammary tumor virus-transforming growth factor-alpha female mice. Cancer Epidemiol Biomarkers Prev 2002, I I (9):836-843.

38. Hoag WG, Dickie MM: Nutrition. In Biology of the Laboratory Mouse second edition. Edited by: Green EL. New York, Dover; 1968.

39. Keenan KP, Ballam GC, Soper KA, Laroque P, Coleman JB, Dixit R: Diet, caloric restriction, and the rodent bioassay. Toxicol $\mathrm{Sc}$ 1999, 52(2 Suppl):24-34.
40. Tannenbaum A: Genesis and growth of tumors. II. Effects of caloric restriction per se. Cancer Res 1942, 2:460-467.

41. Tannenbaum A: Host and environmental factors in cancer research. Acta Unio Int Contra Cancrum 1959, 15:861-863.

42. Colombo M, Kruhoeffer M, Gregersen S, Agger A, Jeppesen P, Oerntoft T, Hermansen K: Energy restriction prevents the development of type 2 diabetes in Zucker diabetic fatty rats: coordinated patterns of gene expression for energy metabolism in insulin-sensitive tissues and pancreatic islets determined by oligonucleotide microarray analysis. Metabolism 2006, 55(I):43-52.

43. Boza |l, Moennoz D, Vuichoud J, Jarret AR, Gaudard-de-Weck D, Fritsche R, Donnet A, Schiffrin EJ, Perruisseau G, Ballevre O: Food deprivation and refeeding influence growth, nutrient retention and functional recovery of rats. I Nutr 1999, 129(7): 1340-1346

44. Hill JO, Fried SK, DiGirolamo M: Effects of fasting and restricted refeeding on utilization of ingested energy in rats. Am J Physiol 1984, 247(2 Pt 2):R318-27.

45. Dulloo AG, Girardier L: $\mathbf{2 4}$ hour energy expenditure several months after weight loss in the underfed rat: evidence for a chronic increase in whole-body metabolic efficiency. Int J Obes Relat Metab Disord 1993, I7(2): I I5- 123.

46. Sato K, Kashiwaya Y, Keon CA, Tsuchiya N, King MT, Radda GK, Chance B, Clarke K, Veech RL: Insulin, ketone bodies, and mitochondrial energy transduction. Faseb J 1995, 9(8):65|-658.

47. Weindruch R, Kayo T, Lee CK, Prolla TA: Microarray profiling of gene expression in aging and its alteration by caloric restriction in mice. J Nutr 200I, I 3 I (3):9I8S-923S.

48. Terpstra AH: Differences between humans and mice in efficacy of the body fat lowering effect of conjugated linoleic acid: role of metabolic rate. J Nutr 200 I, I 3 I (7):2067-2068.

49. Shelton H: Fasting for Renewal of Life. 2nd edition. Tampa, FL, American Natural Hygiene Society, Inc. ; 1974:314.

50. Sorensen M, Sanz A, Gomez J, Pamplona R, Portero-Otin M, Gredilla $R$, Barja G: Effects of fasting on oxidative stress in rat liver mitochondria. Free Radic Res 2006, 40(4):339-347.

5I. Seyfried TN, Bernard D, Mayeda F, Macala L, Yu RK: Genetic analysis of cerebellar lipids in mice susceptible to audiogenic seizures. Exp Neurol 1984, 84(3):590-595

52. Macala LJ, Yu RK, Ando S: Analysis of brain lipids by high performance thin-layer chromatography and densitometry. J Lipid Res 1983, 24(9): I243-I250.

53. Hauser EC, Kasperzyk JL, d'Azzo A, Seyfried TN: Inheritance of lysosomal acid b-galactosidase activity and gangliosides in crosses of DBA/2J and knockout mice. Biochem Genetics 2004, 42:24I-257.

54. Folch J, Lees M, Sloane-Stanley GH: A simple method for the isolation and purification of total lipids from animal tissues. J Biol Chem 1957, 226:497-509.

55. Seyfried TN, Ando S, Yu RK: Isolation and characterization of human liver hematoside. J Lipid Res 1978, 19(5):538-543.

56. Kasperzyk JL, d'Azzo A, Platt FM, Alroy J, Seyfried TN: Substrate reduction therapy reduces ganglioside content in postnatal cerebrum-brainstem and cerebellum in a mouse model of GMI gangliosidosis. J Lipid Res 2005.

57. Lang TA, M. S: How to Report Statistics in Medicine. Philadelphia , Amer. College Physicians; 1997.

Publish with Bio Med Central and every scientist can read your work free of charge

"BioMed Central will be the most significant development for disseminating the results of biomedical research in our lifetime. "

Sir Paul Nurse, Cancer Research UK

Your research papers will be:

- available free of charge to the entire biomedical community

- peer reviewed and published immediately upon acceptance

- cited in PubMed and archived on PubMed Central

- yours - you keep the copyright 